\title{
Pacific Utopias and National Identities in the Twenty-first Century
}

\author{
Sina Va'ai, National University of Samoa \\ There is not one Pacific \\ Only one common theme \\ That development is certain \\ Though foreign \\ And coconuts will continue \\ To fall \\ The Pacific Ocean will camouflage \\ superficial dreams \\ and the faint sound of drums \\ will still be heard \\ if we pause a while to listen \\ Vaine Rasmussen
}

Vaine Rasmussen's concluding verse of her poem Our Pacific draws in literary form the broad concern of this essay, namely, the multiple visions, which include the dreams of Pacific utopias or paradises and Oceanic identities in our contemporary Pacific, the fact of modernity and development introducing the foreign/strange and global into our everyday existence and the perennial constants of the measina, the ideal beauty or treasures of culture and tradition symbolised by the coconuts, the Ocean and the drumbeats, which provide nourishment for our imaginative and ethical growth as human beings.

In November 2003, the Government of Samoa celebrated the fiftieth anniversary of the release of the first motion picture which was filmed on location in Samoa. The movie, Return to Paradise, starring Gary Cooper, was based on one of Michener's narratives about the South Pacific. According to Dunleavy, 'this was the first time in recorded 
motion picture history that a government had taken the initiative for such a cinematic celebration’ (Dunleavy 2004, 14). Such local initiatives signal the importance attached by national governments to promoting the image of the Pacific Paradise as an integral part of the discourse of tourism, a major source of revenue for many Pacific island nations (Misa Telefoni 2002, www/treasury.gov.ws).

These Pacific utopias are usually represented as far removed from the tensions of the world haunted by the threat of terrorist activities and destruction which undermine global peace and security, especially post September 11, 2001. Yet if we examine the literary form of history telling and read the literary texts as Said advises, '.... as a way of better understanding the human adventure and the cultural context from which [they] came' (Said 2000, 448), it is clear that creative writing from the Pacific is full of the same angst, frustrations and dilemmas regarding multiple postcolonial identities and nationalism as those fictions from their metropolitan neighbours.

This article will contextualize the writing from the Pacific by remembering the pasts from which it grew and then move on to a discussion of Albert Wendt's Ola and Vilisoni Hereniko and Teresia Teaiwa's drama Last Virgin in Paradise with a view to highlighting the conflicts emerging especially in regards to the issues of political and cultural identities, indigeneity and the Pacific Paradise. It will focus on the ways that colonialism and postcolonialism impacted on the Pacific and their related effects on the quest by Pacific Islanders for new post colonial cultural identities and liberalization from the past on conformity to the literary standards of European metropolitan centres. Interrogating concepts involving colonizers and the colonized in the politics of dominance and subservience, an imperial centre and its peripheries or margins, the notion of a culturally superior European self versus the 'Others' of Empire, the orientalising vision which provided an imaginative cultural construct of the Pacific, romanticizing and exoticising its 'islands and beaches' (Denning 1980), peoples and cultures and the function of creative writing in promoting and affirming a decolonized sense of self, national identity and cultural liberty in Pacific countries, are important gridlines for the discussion and analysis of the creative writing which is the article's focus. 
Early exploratory excursions by European men of empire laid the foundation for the literary portrayal of Pacific Islanders and their 'world' and the development of stereotypes and dominant images of the South Seas which could be fruitfully linked to Edward Said's Orientalism, defined as ‘an internally structured archive’(Said 1979, 58) built up from the literature written by Europeans. This archive was based on past encounters between West Europeans or Occidentals and the peoples of the East or Orient whereby the countries and peoples of the Orient were typed onto the West's imagination, divided into several categories, alternating 'between being an Old World to which one returned, as to Eden or Paradise, there to set up a new version of the old and being a wholly new place to which one came...to set up a New World' (58). This archive presented, in Said's opinion, a false perception of the Orient but it provided Europeans with imaginative lenses allowing them to rationalise their colonial hegemony over the Orient.

As for the issue involving the connection of power and knowledge and the images employed in the pursuit of colonial domination over the Pacific, the Cook voyages' representations are particularly pertinent and described as falling into two different kinds. One incorporated charts and coastal profiles as an aid to ships' navigators together with drawings of flora and fauna to detail what was of commercial value, such practical, utilitarian images being 'specific...(using) art in the service of science, commerce and the flag' (Said 1979, 58). The second involved generalised emotive images evoking the paradise or purgatory alluded to earlier, helping mobilise Europeans, like administrators and missionaries, in their decisions to enter the Pacific 'in their thousands and eventually dominate it’ (191). Thus the Pacific viewed imaginatively from Europe became what Daws called ‘a dream of islands' (Daws 1980, xi) where in the 19th century especially, the dream of a Pacific utopia involved the scenario where 'the white man stood above all others...(and)...deserved to rule: this was the truth that made the West strong...and it was a truth that the West set out to teach all the peoples of the world' (20). 
Colonialism produced the fictional worlds of Oceania staked out imaginatively in varied shades of attractiveness and repulsiveness by early European writers who had spent time travelling in various capacities and living in the South Seas like Herman Melville, (notably his novel Moby Dick and more importantly, for their emphasis on escapism, freedom and sexuality, his first two novels, Typee and Omoo, set in the Marquesas and Tahiti respectively), Charles Warren Stoddard, Robert Louis Stevenson, Paul Gauguin (whose Noa Noa along with his paintings of immobilised, available Polynesian women continued the Rousseauian idea ${ }^{1}$ ) Louis Becke, Joseph Conrad and Somerset Maugham (Melville 1846,1851, Stoddard 1873, Stevenson 1893, 1894; Gauguin 1957; Becke 1906; Conrad in Watts 1990; Maugham 1985). In his essay examining European literary responses to the South Seas, Subramani divides this colonial fiction into three categories: the first where the South Pacific provides 'local colour', as seen in the fiction of Stoddard's; the second where it is used simply as exotic background for narrative adventure, as with the novels of Robert Louis Stevenson; and the third, where it is symbolic in nature, as is evident in the works of Melville, Conrad and Maugham (Subramani 1976a, 6). His comments, with regard to the fiction of the three authors mentioned in the latter category, are pertinent; 'A striking feature...is the absence of genuine Polynesian characters' (17) and 'Generally, the image of the Polynesian falls into two parts; he is either a terrifying savage...or he is a friendly primitive ... The Polynesian character is no more than either a Caliban or a Friday’ (17).

Later, contemporary writers, notably James Michener ${ }^{2}$ and Paul Theroux (Michener 1967; Theroux 1992), continued to represent Oceania with their 'imperial eyes' exemplifying what Pratt labels:

a discourse of negation, domination, devaluation and fear...the official metropolitan code of the 'third world', its rhetoric of triviality, dehumanisation and rejection coinciding with the end of colonial rule ... the rise of national liberation movements and accelerated ... processes of modernization, industrialising and urban growth in many parts of the world (Pratt, 1992, 220).

\footnotetext{
${ }^{1}$ See Teaiwa 1994 for an Islander critique of Noa Noa, read alongside Hau'ofa's Kisses in the Nederends. ${ }^{2}$ Some of Michener's stories in Tales of the South Pacific were adapted by Rogers and Hammerstein into a famous Broadway musical called South Pacific which was later made into a movie. See Sutton 1995, 127139.
} 
It is therefore evident that representations of South Pacific Islanders by Europeans looking in from the outside involve what Foucault would describe as a 'technology of the self ${ }^{3}$ which legitimised colonial paternalism and domination in the past and postcolonial interventions in the present with stereotypical images of the passive, happy, hospitable Islander, living serenely in the security of the Pacific Paradise.

In early 1976, in the first independent issue of Mana, Albert Wendt wrote of the collective, creative movement seen in the renaissance of Pacific creative arts and in the flowering of literary and artistic productions, as a movement 'towards a new Oceania' (Wendt 1976, 49-60) redefining and reconstructing the cultures of the region into newness, free from the 'wounds of colonialism' (54) and 'based firmly on their own pasts' (53). Two years later in 1978, Satendra Nandan’s address; 'The Fiji Indian: A Complex Fate' (Nandan n.d., 35), described how the Fiji Indian, the main migrant group in Fiji, was becoming aware of his fate as a Pacific Islander which required a sea-change that needed to:

seek, establish and foster new relationships with Pacific neighbours, both big and small leading to a dissolution of complexes when the Fiji Indian could say unselfconsciously 'these are our people, this sea of islands make up our country' and the multicultural islands of Fiji would stand as beacons of light in a world of encircling gloom (Nandan n.d., 41).

This statement was made before the 1987 coups and was echoed in late 1993, when Epeli Hau'ofa published his theoretical essay 'Our Sea of Islands' in a book titled A New Oceania; Rediscovering Our Sea of Islands (Hau'ofa 1993). Since that time, and especially meaningful after the 2000 political coup in Fiji, Hau'ofa has refined his ideas in two essays titled 'The Ocean in Us' and 'Epilogue: Pasts to Remember'. Hau'ofa called for a liberation of the mind, especially amongst Pacific Islanders, in the way that Pacific island nations and their inhabitants are seen and represented. This newness of seeing involves a reclaiming, or a rediscovery of, the 'ancient truth' of the vastness and

\footnotetext{
${ }^{3}$ Foucault 1972, 16-49. 'Technologies of the self' are defined as that which 'permit individuals to effect by their own means or with the help of others a certain number of operations on their own bodies and souls, thoughts, conduct and a way of being, so as to transform themselves in order to attain a certain state of happiness, purity, wisdom, affection or immorality (and) ... is associated with a certain type of domination' (18).
} 
richness of the Oceanian 'pasts', in which Islanders interacted in large exchange communities across this vast 'sea of islands'. In his later essay, Hau'ofa states:

A Pacific Islands regional identity means a Pacific Islander identity. But what or who is a Pacific Islander? The issue should not arise if we consider Oceania as comprising human beings with a common heritage and commitment, rather than as members of diverse nationalities and races. Oceania refers to a world of people connected to each other ...We have to search for appropriate names for common identities that are more accommodating, inclusive and flexible than what we have today (Hau’ofa 1987, 36).

Across almost three decades, the cry from Pacific writers/theorists was still basically about the same struggle for recognition and reassertion of cultural identity and selfhood. Wendt states emphatically: 'We must not consent to our own abasement' (Wendt 1976a, 54) and the same sentiment is echoed by Hau'ofa: 'We must not let anyone belittle us again' (Hau'ofa 1993, 16).

Ngugi Wa Thiong'o, in a similar call for the decolonisation of the African mind, described the legacy of empire very succinctly as a 'cultural bomb' (Ngugi 1986, 3), the effect of which is to 'annihilate a peoples' belief in their names, in their languages, in their environment, in their heritage of struggle, in their unity, in their capacities and ultimately in themselves' (3). Even more telling is the effect of imperialism on their past, which is then viewed as 'one wasteland of non-achievement' (3). Thus the wounds of colonialism cut back through the heritage of the past, into the now of the present and reaches over the horizon into the future. In this context, creative writing for Pacific Islanders and migrants like the Fijian-Indians who have been transplanted to an island home in the Pacific, can be seen, as Manoa puts it, as an attempt 'to harmonise the split in themselves, and the splits in their changing cultural environments', (Manoa 1996, 69) to feel complete in a new world order ${ }^{4}$ that maps out for colonised and decolonised peoples experiences that emphasize their fragility and dependence.

After colonisation comes the desire to be liberated, to write out the resilience of Pacific peoples and their ability to survive the impact of imperial domination, blending the 'received goods' from the West with those of their own indigenous homelands. There is a

\footnotetext{
${ }^{4}$ President Bush's term in describing the future of world economies in relation to the world superpower, the USA.
} 
need to celebrate and to make sense of the many facets of the Pacific self which is made up of many voices and shifting identities - to externalise, to put outside what was previously held captive, often in turmoil, inside. This process of turning the inside out, creatively speaking, leads to a process that brings healing, as 'the (Pacific) other', the coloniser, is allowed to see the inside view, the emotional and cultural terrain/s of the decolonised writer and his/her experiences, to enter imaginatively into previously silenced/silent cultural spaces and stories.

For the indigenous peoples of Oceania, their spaces incorporated the vast Pacific Ocean and strings of islands, of varying sizes and types. Hau'ofa describes the world-view of these ‘ocean peoples' as conceiving of their universe as not only land surfaces but also;

the surrounding ocean as far as they could traverse and exploit it, the underworld with its firecontrolling and earth-shaking denizens, and the heavens above with their hierarchies of powerful gods and named stars and constellations that people could count on to guide their ways across the sea (Hau'ofa 1993, 7).

These Islanders whose ‘world was anything but tiny' (Hau’ofa 1993, 3), engaged in cultural exchanges centuries before European contact with peoples of the Pacific. The focus of colonisation was to divide up Oceania into 'islands in a far sea' (3) which bound colonial and postcolonial administrators to notions of smallness which often bred a mental set of dependency and despair. Hau'ofa, in turning this notion of smallness around from tiny 'islands in a far sea' to the vast expanse of a 'sea of islands', makes for a shift in emphasis which is supported by the belief held by many Pacific Islanders, especially by those in Polynesia, that they did not originate from anywhere outside their own island groups, that in fact their homeland is the centre from which other migrations occurred. This autochthonous theory, which is advocated by most Samoans and supported by its oral history and traditions, ${ }^{5}$ is represented by a response from a Manua ${ }^{6}$ orator to a statement by Sir Peter Buck about Polynesian migration. 'The Polynesians may have come from Asia, but the Samoans, no. We originated in Samoa' (Buck 1938, 294), the orator told the Maori anthropologist. The concept of a sacred centre denoted in the names

\footnotetext{
${ }^{5}$ Samoans refer to their legends of the creator of Samoa as Tagaloa and the absence of stories of migration from other places which feature in legends and traditions of many of the other Polynesian groups.

${ }^{6}$ Manua is the group of Samoan islands forming part of American Samoa.
} 
'Samoa' - (Sa meaning sacred, Moa meaning heart or centre) and Tongatapu (tapu meaning sacred, thus sacred Tonga) testifies to traditions of autochthony. Similarly in Fiji, it has been claimed that 'there are no traditions in any way indicating the direction of their primeval migrations. On the contrary, a tradition states that the Fijians were created in Fiji, and did not migrate from another land' (Pritchard cited in Geraghty 1997, 27).

Hau'ofa's paper stimulated responses and discussion within the University of the South Pacific (USP) community during its Silver Jubilee Year in 1993, an important year for the USP and for the Pacific region. Over a decade later, it is still an on-going and important debate because it involves the horizons of minds and imaginations of the peoples of the South Pacific in the desire to free them from past colonial constraints imposed from without and newer neocolonial and postcolonial constraints imposed from within. The debate is also an attempt to remind the peoples of the Pacific of their origins in a vast ocean whilst not forgetting the present challenges of development in a modern world.

Change is a constant in modern-day life throughout the world and is most marked in the countries of the Pacific. Modernisation and migration have put tradition under threat and changes have occurred at all levels; social, economic, political and personal. The creative writer in the Pacific, while being shaped by these changes in which s/he lives, fulfills many functions with his/her fiction. These can include commentator, shaper and prophet. In these postcolonial times in the Pacific, where a national self/selves and identity/identities are slowly being addressed and defined, these roles are even more crucial. The creative writer in the contemporary Pacific is often like a signpost, pointing the way beyond, to a future (whether personal, national, regional, global) which is imaginatively shaped and sketched. These outlines are the fruit of multiple, overlapping, blended, regional and global influences. The personal journey of the creative writer in these instances involves what Albert Wendt calls ‘maps and fictions’ (Wendt 1991b). He observes:

We each have preferred maps, learned maps-what we believe our cultures, our nations, ourselves were and are. Our maps may be our neighbours' fictions, we read one another through what we believe, through the mirrors of who and what we are. Those maps and fictions are all in the spiral 
which encompasses the story of us in the ever-moving present, in the $V a$, the space between all things which defines and makes us a part of the unity that is all (Wendt 1991b, 181).

This definitive space between all things, the $v a$ and va-tapuia, are concepts in Samoan society involving human relations/relationships in time and space, whether it is mythological (as in the watery spaces out of which Tagaloa, the Polynesian god, created the heavens and the earth) (Kramer 1994, 539-544), temporal or personal and associated with these relations are tapu (conventions), laid down as a guide to interaction and appropriate behaviour. Aiono F. Le Tagaloa, former Professor of Samoan Studies at the National University in Apia, explains:

there is the va-tapuia between brother and sister (the feagaiga relationship, the equivalent to a 'sacred covenant'); the va-tapuia between the parent (especially father/mother) and offspring; there is the va-tapuia between male and female, between male and male - female and female; there is the va-tapuia between host and guest, there is the va-tapuia between matai; there is the $v a$ tapuia between the dead and the living; there is the va-tapuia between man and his environment sea and sky, flora and fauna; then there is the va-tapuia between the created and the Creator. (Tagaloa personal communication 1994).

These relationships are described as sacred (Tagaloa personal communication, 1994) with notions of mutual respect and courtesy that prescribe the norms of behaviour in Samoan society. The spaces in-between, the $v a$, operates not only at a physical and relational level but also metaphorically to describe postcolonial situations where Pacific Island peoples, especially creative writers who work within the realm of the imagination, find themselves negotiating spaces between and across different cultural worlds, redefining and repositioning themselves in the process.

Wendt's notion of maps and mirrors ${ }^{7}$ has a resonance in Said's theory of orientalism, ${ }^{8}$ explicitly interrogating as it does the linkages between power and knowledge and how

\footnotetext{
${ }^{7}$ Maps and mirrors are also used by Borges, whom Wendt lists along with Camus and other writers whose books are selected by Galupo to take with him when he returns to Sapepe (Wendt 1981, 366 as noted by Subramani 1985, 157).

${ }^{8}$ Said examined orientalism as a discourse, using Foucault's concept (Foucault 1972 \& 1979), whereby the 'Orient' (not only adjacent to Europe - but also the place of Europe's greatest and richest and oldest colonies, its cultural contestant, one of its deepest and most recurring images of the Other)' (Said 1979, 1) existed primarily as a project of the West, serving to justify the treatment and exploitation of peoples culturally homogenised under this label. Thus orientalism is a 'style of thought based upon an ontological and epistemological distinction made between the Orient (most of the time) and the Occident' (Said 1979, 2) whereby the West or the Occident dominated, restructured and had authority over the Orient. Gramsci's notion of hegemony (Gramsci cited in Said 1979, 7-8) is employed, consequently allowing for 'a flexible positional superiority which put(s) the Westerner in a whole series of possible relationships with the Orient without ever losing him the relative upper hand' (Said 1979, 7).
} 
these cultural constructions impact on colonised peoples. It is pertinent to examining the ways that the South Pacific, and especially Polynesia (formerly labeled 'the South Seas') was exoticised, romanticised and articulated in the European imagination.

At a Pacific literature conference titled 'From the Inside Out - Theorising Pacific Literature' held at Hawaii in September, 1994, the focus of debate was the indigenising of literary theory pertaining to the waves of creative writing emerging from the Pacific. It featured a presentation by Hereniko and Schwarz which looked at the role of the critic in a colonized Pacific. The authors called for critics to be alert 'to the complexity of writing that is being produced in the Pacific in the 1990s and the absence of a homogeneous or unitary perspective among indigenous writers’ (Hereniko and Schwarz 1994, 6). Reference was made to the Faber controversy, ${ }^{9}$ which labeled Pacific writing as unsophisticated. The authors also examined and rejected four reviews of Hereniko and Teaiwa's 1993 play, Last Virgin In Paradise, as being unsatisfactory and a proposal for a holistic 'author-friendly' approach to literary criticism of Pacific writing was made. This new approach would take into account cultural, historical and social contexts where the critic assumes the role similar to that of a Samoan tulafale (talking chief) ${ }^{10}$ who employs the process of feutagai (consultation). While noting that 'not everyone can be a tulafale', it was also contended that the role of critic of Pacific literature 'should be reserved only

\footnotetext{
${ }^{9}$ This controversy was also mentioned by Albert Wendt in his keynote address and was the subject of informal discussion. Birkett (Birkett 1994), in the Guardian Weekly, reported that the editor of the short story anthology, C. K. Stead, had expressed reservations about broadening the scope beyond New Zealand, adding that island writing was relatively unsophisticated in execution but that he may be able to add 'mainly Fiji and Samoa to New Zealand and the Cook Islands if there is a writer there worth including' (my emphasis) (Stead cited in Birkett 1994). The action of several Maori writers and Albert Wendt, in withdrawing their stories from the collection, seemed an appropriate protest against such an outdated and discriminatory attitude. Stead expressed regret in 'A Note On Absences' (Stead 1994, xv-xvii) at the absences in the collection of these major Pacific writers and added pointedly, in relation to Wendt, that this regret in Wendt's case was because 'his short stories, before his recent two novels, Ola and Black Rainbow, which suggest some kind of collapse of his talent (my emphasis), represent some of the best in Pacific island writing' ( xvii). In the face of such blatant cultural imperialism, it is obvious that the journey towards a Pacific, postcolonial, independent self/selves is still impeded by the wounds of colonialism's culture.

10 'The tulafale speaks on behalf of the chief, explains or clarifies when necessary, and interacts with the rest of society regarding the intentions of the chief. The tulafale can also criticise the chief - in a loving and constructive manner - when necessary. This relationship between the tamalii "high chief" and tulafale "talking chief" known as feutagai in Samoa, is what we propose as a preferable alternative to the "expert" posturing endemic in literary circles today’ (Hereniko \& Schwarz 1994, 6).
} 
for those who know Pacific cultures and peoples well and have a broad knowledge of the literature’(6).

The authors proposed a decolonising of literary criticism for the Pacific declaring that 'the standards of judgment must come from inside Pacific Islands cultures and they should be informed by the issues, viewpoints, forms of rhetoric and artistic modalities of Pacific cultures' (Hereniko and Shwarz 1994, 14). The ideas raised in the proposal have yet to be fully explored and are debatable but are powerful, delineating present as well as future struggles. These struggles, similar to those of other decolonised writers in postcolonial societies are concerned with critical approaches which adopt a dialogic ${ }^{11}$ rather than a monologic stance, a postcolonial as opposed to a colonial view which attempts to affirm the various aspects of postcolonial Pacific identity and to recover the dignity which had been lost in the fractured colonial past. Subramani's 1999 address at the SPACLALS conference Imagining Oceania also emphasized that Pacific peoples will need all the "resources of their imaginations "to chart alternative paths" in the years of the new millennium, constructing answers to questions about postcolonial identities and other pressing issues of regional importance’ (Subramani 2003, 12).

I will now discuss two works of fiction, firstly a novel by Albert Wendt, the Pacific's best-known international writer, and a drama by Vilisoni Hereniko and Teresia Teaiwa. All three writers are academics, the first two teaching at the University of Hawaii and the latter at Victoria University in New Zealand. In Ola, Wendt takes on the narrative voice of a woman, reshaping the life of one Olamaiileoti (a name defined as 'born from death', as her mother had technically died before the surgeons operated to remove the child and

\footnotetext{
${ }^{11}$ See Holquist 1981. Bakhtin (1961, 336-337) expresses his concept of dialogism as follows: 'Life is by nature dialogic. To live means to participate in a dialogue: to ask questions to heed, to respond, to agree and so forth. In this dialogue a person participates wholly and throughout his whole life: with his eyes, lips, hands, soul, spirit, with his whole body. He invests his entire self in discourse, and this discourse enters into the dialogic fabric of human life, into the symposium of the world'. In relation to the concept of self and other, Bakhtin writes 'This other human being whom I am contemplating, I shall always see and know something that he, from his place outside and over against, cannot see himself: parts of his body that are inaccessible to his own gaze (his head, his face and its expression) the world behind his back... are accessible to me but not to him. As we gaze at each other, two different worlds are reflected in the pupils of our eyes... This ever- present excess of my seeing, knowing and possessing in relation to any other human being is founded in the uniqueness and irreplacebility of my place in the world'. (Bakhtin 1990, 23.
} 
now seen by the aiga as a resurrection, a reincarnation of her dead mother) (Wendt 1991a, 14) Farou Munroe_-or Ola ('life') for short. This life, and a rich assortment of papers, (including diary entries, personal letters, poems and other fictions, an account of her childhood and youth and her father's final years), are bequeathed to the author (in the person of Pati Tuaopepe ${ }^{12}$ ) in three beer cartons, left on his front veranda anonymously. In an attached letter to the writer, whom she admired, Ola expresses her hope that his rearrangement of her papers will help her 'read/find a meaning to (a) wasted life' (7).

Ola's story takes her, as a companion to her seventy-five-year-old father, Finau, on a pilgrimage to the Holy Land, the land of Jesus' birth. The trip is a surprise birthday gift from the aiga to the old man with roots in Sapepe, the fictional village situated on the western tip of Upolu, created for Sons and used also in Leaves. As she explains for the reader:

Nearly all of us Samoans are raised on the Bible, and after over one-hundred-and fifty-years of Christianity (mainly fundamentalist) we know almost nothing of our ancient religion. My father's generation knows more about the biblical Holy Land (geographically, historically, spiritually) then our own country and more about it than the modern Israelis. The biblical prophets, heroes and villains, the courageous saga of the Israelites, Jesus and His disciples are a vital part of their everyday lives (Wendt 1991a, 11).

Through this journey, Finau's reactions to this received (from London Missionary Society missionaries) and imagined Holy Land, as well as his defining Samoanness are delineated together with the events in Ola's life, both in the past and in the present. The narrator, in a conversational tone, draws on the fagogo style of Wendt's previous texts, drawing the reader closer with her direct address and expressions like 'Aue’ (Wendt 1991a, 9, 44, 49), an expression used to convey emotions of surprise or suffering. The narrative takes on a global dimension, with shifts occurring to describe episodes of Ola's life in Western Samoa, New Zealand, Japan, New York and of course, hinging on the basic narrative, in Israel, with plane stopovers in Honolulu and Athens. Ola herself by the end of the novel, is three-times divorced, with an illegitimate son, Pita, conceived between her first and second husbands from a possible ‘gaggle of men' (113) she had used to assuage her selfdestructive loneliness.

\footnotetext{
${ }^{12}$ Pati is Albert and Tuaopepe is Wendt's Samoan family matai title. See Afterword of Ola, 347.
} 
Raised in the Vaipe in the town of Apia, she receives a scholarship for secondary education in New Zealand. She ends her two-year-old marriage to her first husband, Matthew Browne, before completing her BA to teach English at Samoa College. It is here that she meets and marries a wealthy Peace Corps Volunteer, Mark Stripter (a marriage which lasts about eight years), who sets up a Pacific Island foundation, after the divorce, to help island countries with his maternal Grandfather's fortune which he has now inherited (there is some doubt cast on the truth of Mark's genealogy and inheritance which is always left hanging; the possibility that he is a trickster is suggested but never finalised). Her third husband, Carl Fischer, is heir to a local Samoan import and export company, himself already supporting two ex-wives and their households. When Ola begins her trip to Israel with Finau, her third marriage is already shaky. Like the protagonist in Sons, Ola too, is unconventional, often feeling out of place in Sapepe and suffering when in love. Her adolescent son, Pita, echoes the father in Sons: 'It's because you see too clearly, even when you don't want to...Lagona (his great grandfather) told me once that to see people and things in all their flaws and weaknesses and not forgive them is to not accept what is' (Wendt 1991a, 286).

Their experiences in Israel provide an emotional bonding for both the father and daughter. Commemorating and honouring the suffering of the six million Jews murdered in the Holocaust, when they visit Yad Vashem, a memorial to the victims, Finau undergoes a spiritual illumination, opening his mind to admit the common humanity shared by all peoples, including the Jews, labeled and stereotyped as the crucifiers of Christ in Christian Samoa. One memory remains vivid and lasts till Finau's death; he even mentions it in his last testament, given to Ola after his death. He tells his daughter:

I'll never forget their eyes ... The eyes were those of owls. And Ola, our family god in pagan times, was the owl ... Square and still I stood in front of the middle pillar ... on a small black shelf (was) the well-used shoe of a child. A worn-out, utterly helpless shoe watching me. And I fled. Rushed out onto the roof of Yad Vashem and the endless, silent scream of God's universe.

..That shoe will be worn by my heart for the rest of my days. It is a perfect fit (Wendt 1991a, 34).

The holy wanderer from Pouliuli is placed firmly in the narrative with his trademark 'silent scream' as was his circle of pebbles at the beginning of the novel in chapter one. 
Self-referentiality becomes a feature of Wendt's works as the texts are gradually woven together from his dominant, imaginative frame.

Later, at a dinner party at a poet's home, the Samoan visitors are asked about their homeland and Finau orates the solo o le va or the Samoan chant of creation, which Ola translates into English. After explaining the Samoan concept of the circle of life in the spiral of the present, in the Va, Finau states; 'The Holy Land has helped me see myself and what I've become. And through that see my beginnings and my country in a new way’ (Wendt 1991a, 216). Finau by his oratory and pride in claiming the ancient beliefs expressed in the song, affirms the old, holistic 'way of seeing' and mourns the immense loss, part of the grounds of defining himself. Inserted into this social conviviality is the story of a young kidnapped boy in Tel Aviv and when Finau declares that the boy is alive, the room of hopeful Jews go along with it, almost as if believing in his prophetic power. At the end of the evening, Ola, 'a drop-out Christian' is to recite the creation chant again, to see, as one in a trance, a vision of her father with the lost boy in his arms, the world once more 'Circled. Healed. Magical' (221).

It is only after the excitement of commercial sightseeing and shopping around the Holy place that they hear that the kidnap victim has been killed. Finau's request to visit the Wailing Wall is understandable and his guilt is manifested in his note 'Please forgive me' which he places into the joint of two stone blocks. Following that though, the invitation to Finau by an old patriarch, part of a group of Yemenite Jews, dancing in procession, to join them is to bring reconciliation and a sense of peace. Ola observes,

Before we veered away from the Wall, my father turned his face to me; it was alive with tears. But how he danced. Held up, above the abyss by the magic of his ancient friends, the boy and the song and the rhythm, his legs and knees stepping high ... How he danced. Beyond forgiveness and grief. (Wendt 1991a, 306).

The pilgrimage has become a journey to explore and affirm the self, and to that end some of Finau's own personal agonies and guilt surface. He tells Ola a part of the family genealogy he has never revealed before, of two dead brothers, tragic figures, the first one Va'a, the eldest and ideal son who provided tautua (loyal service) to their strict taskmaster father, and the aiga and who had died early of an ulcer. The second brother, 
Pese, who died at eighteen, was deformed and Finau, even though two years the younger, was expected to look after him, so to make that caring easier, he trained Pese to imitate everything he did as a game. After Pese's death, the younger brother realised that the need between them had been mutual and that indeed, he misses 'his second self' (Wendt 1991a, 166).

Ola’s new found uncles, part of her Dead, are only some of the people cast to play out incidents from the various 'pasts' that inform the narrative and flesh out a fictional life, from all the papers left to the artist to reshape. Others from her boarding school days as a scholarship student in New Zealand are also important, especially the story concerning Gill, her closest Pakeha friend from school, and the latter's struggles to truthfully claim her Maoriness after years of her Maori mother and Pakeha father hiding the fact. This truth, about her true identity parallels Ola's search and Finau's reclaiming of their 'pasts' to understand previously hidden and denied aspects of their true selves. The undertones of racism are clear and the tragic accident which claims Gill's life and that of one of her daughters, Karin, happens in her homeland, described by Gill as 'Kiwiland, colonial empire of racists, bigots, male-chauvinist rams, and rugby players who love South Africa and apartheid' (Wendt 1991a, 68).

The return to Samoa is eventful; Carl has filed for divorce and Ola goes with Finau to Sapepe, where Malo Tauilopepe Galupo is the highest ali' $i$, his wealth expanding for everyone to witness. He is still sinister, though charismatic, and as to be expected, even more 'into power, into the controlling, using and manipulating of it' (Wendt 1991a, 319); and Ola finds his eyes watching, measuring her, an uncomfortable situation for the person watched. With his health declining, Finau makes a deathbed request, a mavaega, that Ola take on the matai title of Lagona, which he has previously refused because of his age. After her initial refusal, Ola (described previously in Israel by Finau as 'the permanent traveller' (142)), accepts when her father whispers into her head 'accept it for the kidnapped boy who was executed in Israel' (34). She had just recalled the first visit she ever made to the village when she was six, memorable for the discovery of the ' $\mathrm{I}$, Me, as separate from the Them and Everything Else' (339). These are reflected in Samoan pronouns, extending outwards from the self; $O a^{\prime} u$, I, me to $O$ tatou, we, us to $O$ tatou uma, all of us. The widening spiral of the $V a$, the space between connecting the ' $\mathrm{I}$ ', the 
'Me' to the 'All-of-Us' in a unity that encompasses everyone is Ola's final concern and as a matai, it is a vital and legitimate concern. As she realises after the burial; 'Today I want nothing, yet my aiga wants everything of me. Today I need nothing, yet I need everyone’ (345).

Wendt amplifies the notions of $\mathrm{Va}$-its workings and implications in its home society, the Sacred Centre in Ola. It is mentioned five times in the chapters leading up to the last will and testament, from chapters 82 to 84 whereas up to that point in the narrative, it is only included twice. This has obvious significance as it is only towards the end of the novel, as Finau's death approaches, that Ola accepts the 'All-of-Us', the 'We' into her consciousness. Prior to that, especially in the episodes connected to Carl, in her affair and later marriage to him, Ola is presented as very cynical, moving amongst the business and political elite of the nation's capital, the cocktail cliques of Apia, witnessing the corruption of her middle-aged peers, most ex-scholarship students like herself, who play their political power games with ease while drinking 'alofa on the rocks' (Wendt 1991a, 294, 260). The combining of alofa (compassionate love) with alcohol implies the cheapening of this basic virtue of the fa'amatai or fa'asamoa, hinting at its commercialisation and degradation. During Ola’s visit to Japan, on a business trip with Carl, Ola talks about 'OLA-DO' (279), (Do being Japanese for 'way'), her way, the way of Life, at that point growing in alofa in her relationship with her third husband-to-be. Also in New York with Mark, she admits her love for the individualistic city where there are 'heaps and heaps of people ... cut off from one another' (112) and where participating in perverted sex shows, ends in feelings of guilt and desperation.

It is only by acknowledging the $V a$ that Ola finds some sense of peace in accepting her self and her identity. 'Our Va with others defines us. We can only be ourselves linked to everyone and everything else in the $V a$, the Unity-that-is-All and now' (Wendt 1991a, 307). Like the Jews in the Holy Land that Finau and Ola met and socialised with, making sense of multiple identities and defining 'homeland' is a preoccupation of the postcolonial present. It entails a resurrection, a reviving of ancient, 'whole' ways of seeing and turning the immense loss suffered under colonialism into a new way of life. 
Wendt's novel puts the diasporic islander under the fictional spotlight, enabling the reader to empathise with the complex dilemmas surrounding the issues of identity for many such individuals in the postcolonial Pacific. The power of the clown (known as han mane'ak su in Rotuma and referred to in Samoan tradition as a fa'aluma) and Pacific comedy is demonstrated in Vilisoni Hereniko's play, Last Virgin in Paradise (Hereniko 1993) which is based on a true story told by Teresia Teaiwa. It explores the same issues as Wendt's novel from another angle, using comedy and Pacific humour to uncover similar insights. The play is subtitled 'a serious comedy' and according to the playwright 'debunks the stereotypical images of Polynesia that have been created by Gauguin in his paintings and by writers like Margaret Mead, Jack London and Somerset Maugham’ (Hereniko 1994, C7). It deconstructs European representations of Polynesians who are often shown by these outsiders as ‘people who aren’t quite fully human’. The two Europeans in the play, Helmut Klinghorst, from no specific country in Europe and Jean, the inevitable Australian anthropologist, visit Marawa (which means happy in Fijian) for different reasons but with the same cultural attitude. Helmut's country of origin in Europe is kept deliberately vague; maybe to reinforce stereotypical sameness that all palagis share the same characteristics and that perception that simplifies all people of the same colour whether white, black, brown or yellow; 'If you've seen one, you've seen them all'. Thus from the Islanders' perspective, Helmut is just like all European 'others' they have seen since colonisation and as Hina suggests to Temanu, he is gullible as well as materially wealthy.

His quest for the 'new' in essence mirrors the colonial endeavour. He tells Jean:

Do you know that I looked everywhere for a virgin wife and couldn't find one? I've been to New Guinea, Vanuatu, Solomons, Fiji, Guam, Saipan, Samoa, Nauru ... I couldn’t find one. Not a single one who is untouched. Then I came here and within two weeks, I find one. Yes, I've found the perfect one (Hereniko 1993, 4).

Jean, who holds a \$20,000 Fulbright grant, says directly to the audience at the end of scene one, 'I'm here to write the definitive work on sexuality among the Marawan people. My book will make me famous ... Coming For Sex, that's the tentative title' (Hereniko, 13). This is an obvious mockery of Margaret Mead's controversial study 
among adolescent Samoan girls in the 1920s titled Coming Of Age In Samoa - A Study of Adolescence and Sex in Primitive Societies (Mead 1928). Jean's behaviour as the 'nosy anthropologist' (Helmut's description) draws an angry response from Temanu, a local Islander just returned from twelve years of education overseas in Australia, as a history graduate from the Australian National University, returning in search of her identity, to find her 'roots'. She accuses Jean of being arrogant, a 'bloody nosy foreigner who cares for nothing but her research’ (Hereniko 1993, 9), lumping her together with Helmut in her scathing condemnation that they're both the same, 'come ... to plunder and steal, to take and take until there’s nothing left that's sacred anymore’ (24).

Helmut's marriage to Hina, the young island 'virgin', and the complications associated with Hina's choice are the focus of the play. Jeke, the local clown, has played the intermediary for Helmut in convincing Hina and her parents that it is better for the young woman to marry a rich palagi, even though the groom is old enough to be the young bride's father. The main motivating factor for the parents is economic, so that Hina can 'send them (the parents) money' and come in visit at Christmas with a bag of presents bought in the metropolitan city. For Hina, the marriage is her chance to see the world and get a good education, and she is willing to take the risks of loneliness and discrimination that Temanu warns her about, even though she is also fearful of the unknown. Temanu becomes personally involved in trying to dissuade Hina from marrying Helmut, when Hina reveals that while Termanu may be confused about her own identity, Hina's family are clear about their relationship with her, the returned, local academic. Hina's words are emphatic; 'I know who you are. You Temanu, daughter of Etika who marry a white woman. Etika is my father's older brother. Your parents take you to Australia for a good education. We related' (Hereniko 1993, 7). This relationship inspires Temanu to commit herself to warning, and if possible, convincing Hina that the marriage should be called off. Hina's insistence as she walks to board the plane that will take her 'out' to the wider world that Helmut is her 'passport' to fulfill the dreams of a global life, ends with a telling retort when Temanu reminds her that she should never forget her roots. Hina replies; 'I know my roots. You come to find roots, that fine but I ...I want to find wings too!' (52). 
The wedding feast in scene two demonstrates Hereniko’s ability to blend a Pacific flavour into his work with traditional forms of Polynesian performance arts like secular clowning, providing a boost to Pacific audiences. They provide local slang, jokes, parody with typical role reversal as seen with Hina's aunt, Mere and Jeke (the use of common Fiji slang 'I love you full speed’ and the answer to Mere’s question 'But are you virgin?' elicits the current Fiji colloquialism emphasising just the opposite of what is said 'Oh yes! B-i-g virgin') combined with Pacific dances like the tuiboto and other Pacific songs, this creates a literary context, reflecting the hybridity of the postcolonial frame. In this theatrical setting, some members of the audience will be privileged and honoured in that it is their mother tongue and their local jokes being used and others, like Europeans, will be excluded in that they may not understand the Pacific language being used by the characters, and consequently the humour and the innuendos contained in the dialogue may be unclear. In this way, Hereniko feels European audiences, like Jean the anthropologist, will begin to

get a taste of what its like for many of us who have to tolerate speaking their language all the time ... so using these languages privileges indigenous languages, gives control to the Islanders, the natives because they are the ones to decide when to switch to their own tongue and lock that message in their own tongue (Hereniko personal communication, 1994).

The use of Pacific languages also makes for more play with words especially with the clowning and the mistranslations of Hina's father's speech at the wedding, allowing the playwright to extend the boundaries of humour and push it to its limits. These creative inclusions provide the local colour and humour which characterise Pacific island festivities.

An interesting feature of the production of the play in Hawaii in September $1994^{13}$ was the inclusion of ancestral spirits, Hina's grandma and grandpa, in traditional velinimeke attire. Ancestral spirits are used by Hereniko in different ways; for example in The Monster (a fanstasy) they perform a threatening role and escalate the dispute whereas in the Last Virgin in Paradise, they play a protective role. Their unscripted addition in the

\footnotetext{
${ }^{13}$ This special performance was attended by many of the participants of the 1994 Pacific Literature Conference.
} 
latter play came about due to Hereniko’s experience during rehearsals for the 1994 run of the play in Hawaii when, as he explained it; 'About two weeks before the show opened, I was driving home and there was this voice ringing in my ears and basically the voice was saying "What about us, the ancestors? You have forgotten about us, we want to be in your play"' (Hereniko 1994, personal communication). The ancestors appear in scene three, looking after Hina when she comes back to the hotel after the wedding feast and actually board the plane with her as she leaves with Helmut for Europe. They are, of course, invisible to Hina and the other human characters living in the contemporary linear time frame and act as a literary mechanism to honour traditional Pacific sensibilities and beliefs that dead ancestors still exist in that outer, unseen, spiritual world to protect members of their families still living in the realm of temporal mortality. Their actions as they wait for Hina and Helmut are playful and bawdy, mirroring the actions of Jeke, as he turns the social order upside down and sets the celebratory tone for the wedding feast. In this sense, the spirits display a freedom from the restraints of the human laws that prescribed their behaviour on earth. The juxtaposing of the two worlds, of the living and the dead, and their continuing interconnections, is now seen as an integral dynamic of the play, linking it to contemporary beliefs held by Pacific Islanders, breathing more life into the action and giving it a sense of completion (Hereniko 1994, personal communication). The use of various Pacific languages, Samoan, Fijian and Rotuman, in the songs for the wedding scene and the farewell in the last scene as well as during the formal speeches made at the wedding by Hina's father, together with the varied stage backdrops for the first three scenes (of a Gauguin painting in the first scene, a kava bowl during the wedding scene and a painting of a large eel about to eat a cowrie shell in the third) entrench this play firmly in the postcolonial Pacific with all its ramifications of hybridity within and across Marawan society. Helmut's drunken trampling on the fine mats during the wedding feast becomes a metaphor for the ignorance and arrogance often displayed by Europeans as they persistently set out to achieve their colonial projects of research and discovery in the Pacific.

In a note to the director, Hereniko suggests: 
casting that brings together people from different Pacific Islands is encouraged and where possible vernacular expressions should be used and a way found to communicate their meanings in English. Another possibility is to have the non-English dialogue in the native language of the local inhabitants wherever the play is performed, for example, using the Hawaiian language in Hawaii (Hereniko 1993, xi).

He adds that the anticipated audience should influence language choices, that the success of the wedding scene will depend on the talents of clowns who know how to make people laugh and involving the audience in the singing of popular songs and in the dancing in the play is also important (xi).

This improvisation, flexibility and innovation adds a Pacific flavour to the play which should make each performance (since it is dependent on the ethnic composition of the audience) unique. The comedy of the play hinges on the fact that Helmut is searching for a lost Paradise, and that while Hina and her people seem simple and naive they are all well aware of the issues and they are just as quick-witted, manipulative and shrewd as others are. They are all very aware of what they want out of life and the advantages as well as the limitations that their small island existence places upon them. Ironically, it is Jean, the anthropologist, who is the virgin and not Hina (these confessions are made to Temanu). Jean is depicted as a very naive outsider with pre-determined expectations and little experience of island life. She tells Helmut in scene three; 'I came here expecting Marawa to be primitive and what do I find? Natives dressed to the ankle, a fledgling feminist from ANU and a toupeed alcoholic from a continent called Europe. We all think that Paradise is a place when all the time it's a state of mind' (Hereniko 1993, 40). This play illustrates many of the conflicts that come from expectations not grounded in the reality of the present-day Pacific.

In conclusion, the complexities, challenges and commonalities in the search for Pacific identities are explored by Pacific writers in various ways demonstrating the multiple nature of this region, as alluded to in Rasmussen's poem. In coping with postcolonial reality, we need to carefully listen and pause to appreciate what is important for our particular cultural identity so that cultural liberty for what we choose as vital and important to post colonial identities is secured and promoted for all who call the Pacific their 'home'. 


\section{Reference List}

Birkett, D. 1994, 'Maori Mafia versus The Pakeha Redneck’ in Guardian Weekly, March 27.

Borofsky, R. 2000, A View from Afar (Middle East) - An interview with Edward Said in Remembrance of Pacific Pasts - An Invitation to Remake History, ed. R. Borfsky University of Hawaii Press, Honolulu, 443 - 452.

Buck, P. 1938, Vikings of the Sunrise, Stokes, New York.

Dening, G. 1980, Islands and Beaches - Discourse on a silent land: Marquesas 1774 1880, University of Hawaii Press, Hawaii.

Daws, G. 1980, A Dream of Islands: Voyages of Self-Discovery in the South Seas, The Jacaranda Press, Milton, Queensland.

Dunleavy. T. 2004, Golden Premiere of First Hollywood Movie Filmed in Samoa in Polynesia, January, Pacificads, Apia, 14.

Foucault, M. 1972, The Archaeology of Knowledge and the Discourse on Language, trans. A.M. Sheridan Smith, Pantheon Books, New York. 1979, Discipline and Punish: The Birth of the Prison, Vintage Books, New York.

Geraghty, P. 1977, 'How A Myth Is Born: the story of the Kaunitoni story', Mana, vol. 2, no. 1, (October), 25-29.

Hau'ofa E, 1987, ‘The New South Pacific Society: Integration and Independence’, in Class and Culture in the South Pacific, ed. Hooper et al, Centre for Pacific Studies, University of Auckland in association with the Institute of Pacific Studies, University of the South Pacific, Suva.

1993, 'Our Sea Of Islands', in A New Oceania: Rediscovering Our Sea of Islands, eds. E. Waddell et al, The University of the South Pacific in association with Beake House, Suva, 2-16.

2000, 'Epilogue: Pasts to Remember' in Remembrance of Pacific Pasts - An Invitation to Remake History, ed. R. Borofsky, University of Hawaii Press, Honolulu, $453-471$.

Hereniko, V., and Teaiwa, T. 1993, Last Virgin in Paradise, Mana Publications, Suva. and Schwarz, S. 1994, “'Talking Chief” The Role of the Critic in a Colonized Pacific', paper presented at conference 'From the Inside Out: Theorising Pacific Literature, (17 September).

Hooper, A., Britton, S., Crocombe, R., Huntsman, J., \& Macpherson, C. 1987, Class and Culture in the South Pacific, Centre for Pacific Studies, University of Auckland in association with Institute of Pacific Studies, University of the South Pacific, Suva.

Holquist, M. ed. 1981, The Dialogic Imagination: Four Essays by M.M. Bakhtin, University of Texas Press, Austin, Texas.

Holquist, M \& Liapunov V, eds 1990, Art and Answerability, University of Texas Press, Austin, Texas.

Kramer, A. 1994, The Samoa Islands, trans. T. Verhaaren, Polynesian Press, Auckland. Manoa, P. 1976, 'Singing in their Genealogical Trees', in Mana Review, vol. 1, no.1, (January), 61-69.

Mead, M. 1943 (1928), Coming of Age in Samoa, Penguin Books, New York. 
Michener, J.A. 1967, Return to Paradise: More classic tales of the Southern Seas, Corgi Books, London.

Nandan, S., n.d, (ms), Beyond Colonialism: Exilic Explorations: Selected Prose 1977 1993, CRNLE, The Flinders University of South Australia, Adelaide.

Pratt, M.L. 1992, Imperial Eyes: Travel Writing and Transculturation, Routledge, London.

Ngugi wa Thiong'o. 1986, Decolonising the Mind - The Politics of Language in African Literature, James Currey in association with Heinemann, London.

Rasmussen V.2000, 'Our Pacific', in Remembrance of Pacific Pasts - An Invitation to Remake History, R. Borofsky (ed.)University of Hawaii Press, Honolulu, pp 399 400.

Said, E.W. 1979, Orientalism, Vintage Books Edition, United States of America.

Stead, C.K. (ed.) 1994, The Faber Book of Contemporary South Pacific Stories, Faber and Faber, London.

Subramani, (ed.) 1976, Mana Review: A South Pacific Journal of Language and Literature, Jan. vol.1, no.1, Mana Publications in assoc. with the South Pacific Creative Arts Society, Suva.

1985, South Pacific Literature: From Myth to Fabulation, University of the South

Pacific, Suva.

2003, 'The Oceanic Imaginary’ in Pacific Epistemologies, Pacific Writers Forum, Monograph Series 1, 1-14.

Sutton M, 1995, Strangers in Paradise: Adventurers and Dreamers in the South Seas, Angus \& Robertson, Sydney.

Theroux, P. 1992, The Happy Isles of Oceania, GP Putnam’s Sons, New York.

Teaiwa T. K., 1994, 'Reading Gaugin’s Noa Noa with Hauofa’s Nederends:Militourism, Feminism and the Polynesian Body or Teha'amana, Makarita and Me', paper presented at the Pacific Literature Conference, Manoa Campus, University of Hawaii, Honolulu, September.

Wendt, A. 1976, 'Towards a New Oceania', in Mana Review, Jan. ed. Subramani, vol. 1, no.1, 49-60. 1991a, Ola, Penguin Books, Auckland. 1991b, 'Pacific Maps and Fiction(s): A Personal Journey', in Perceiving Other Worlds, ed. E. Thumboo, Times Academic Press, Singapore. 